\author{
SOME LESSONS \\ FROM THE YIELD CURVE
}

John Y. Campbell

Working Paper No. 5031

\author{
NATIONAL BUREAU OF ECONOMIC RESEARCH \\ 1050 Massachusetts Avenue \\ Cambridge, MA 02138 \\ February 1995
}

I am grateful to Sydney Ludvigson and Chunsheng Zhou for able research assistance, and to Glenn Rudebusch, David Wilcox, David Zervos, and the editors of the Journal of Economic Perspectives for many helpful comments. This paper is part of NBER's research programs in Asset Pricing and Monetary Economics. Any opinions expressed are those of the author and not those of the National Bureau of Economic Research.

(C) 1995 by John Y. Campbell. All rights reserved. Short sections of text, not to exceed two paragraphs, may be quoted without explicit permission provided that full credit, including $\odot$ notice, is given to the source. 


\title{
SOME LESSONS \\ FROM THE YIELD CURVE
}

\begin{abstract}
This paper reviews the literature on the relation between short- and long-term interest rates. It summarizes the mixed evidence on the expectations hypothesis of the term structure: when long rates are high relative to short rates, short rates tend to rise as implied by the expectations hypothesis, but long rates tend to fall which is contrary to the expectations hypothesis. The paper discusses the response of the U.S. bond market to shifts in monetary policy in the spring of 1994 , and reviews the debate over the optimal maturity structure of the U.S. government debt.
\end{abstract}

John Y. Campbell

Department of Economics

Littauer Center

Harvard University

Cambridge, MA 02138

and NBER 
The relationship between short- and long-term interest rates - the yield curve or term structure of interest rates - is a subject that many people are happy to ignore, until the moment when they are saving for retirement and must choose between a bond fund and a money market fund, or are borrowing to buy a house and must choose between a fixed-rate or an adjustable-rate mortgage. At such times the term structure of interest rates may become unexpectedly fascinating.

The yield curve is equally important for economic policymakers, but like private individuals, they may neglect the subject until it forces itself on their attention. In 1994 the term structure moved to the center of debate on U.S. economic policy. The Federal Reserve became intensely aware of the yield curve as initially modest increases in short-term interest rates provoked unusually sharp responses in long bond yields. Meanwhile, the U.S. Treasury began to shorten the maturity of the government debt in the hope of lowering federal interest costs.

The academic literature on the term structure is enormous, and it continues to expand whether or not the subject is in fashion. Fortunately, the literature has improved in quality in the 25 years since Ed Kane's (1970) half-serious jibe: "It is generally agreed that, ceteris paribus, the fertility of a field is roughly proportional to the quantity of manure that has been dumped upon it in the recent past. By this standard, the term structure of interest rates has become ... an extraordinarily fertile field indeed." I first summarize recent research on the term structure of interest rates and then relate it to recent swings in the bond market and the government's choice of debt maturity. ${ }^{1}$

\section{Understanding the Term Structure}

Bonds, or fixed-income securities, have traditionally been defined by the fact that they make payments to investors that are fully specified in advance. Thus, to value a bond one need not forecast random future payments but can simply discount known payments to the present. This makes the bond pricing problem particularly clean and attractive to economic theorists. ${ }^{2}$

In practice, of course, many bonds deviate from the theoretical ideal. Because some issuers of bonds may default, the payments on their bonds are in fact random. During the 1980s, this became particularly obvious with the failure of some Third World countries to make scheduled interest payments on loans and with the development of junk bonds, a class of securities with enough default risk to be intermediate 
between traditional bonds and equity. Some bonds may also have special provisions that complicate their pricing. Callable bonds, for example, grant the borrower the right to repurchase the bond at face value at a time of the borrower's choosing; this right can be thought of as an option which is given to the borrower at the time the security is created. It has considerable value, so callable bonds cannot be priced as if they were pure fixed-income securities.

\section{Some basic concepts}

U.S. Treasury securities approach the theoretical ideal most closely, since they have negligible default risk and in recent years have had no call provisions. ${ }^{3}$ Accordingly the remainder of this article concentrates on Treasury securities, which come in two main varieties. Treasury bills promise to make a single payment, known as face value, at a particular date in the future. This date is called the maturity date, and the length of time to the maturity date is called the maturity of the bill. Bills always have a maturity of one year or less. Fixed-income securities of this sort, which make a single payment at a specified future date, are known as zero-coupon securities.

Treasury notes and bonds have maturities at issue greater than one year; they promise a stream of small payments, known as coupons, every six months until the maturity date, when a final coupon and a large final payment of face value are made. These coupon-bearing securities can be thought of as packages of zero-coupon securities. In recent years coupon-bearing securities have been "stripped" into simpler packages of zero-coupon securities. A five-year Treasury note, for example, makes coupon payments every six months for five years, when the face value also comes due. The note can be divided up and sold as 10 separate zero-coupon bonds, one for each payment date, or as a "strip" of coupon payments together with a zero-coupon security that pays the face value of the note at maturity. As a result of this process, zero-coupon securities with long maturities are now traded.

Even for the period predating strips, the prices of hypothetical zero-coupon securities can be estimated from the observed prices of coupon-bearing securities; in what follows I shall use the zero-coupon price data of McCulloch and Kwon (1993), which are estimated using the methods of McCulloch $(1971,1975)$.

Since a zero-coupon bond makes a single known payment of face value at the maturity date, an investor is assured of a known return over the life of the bond. One measure of this return is the bond's simple yield to maturity. For expositional 
convenience I shall assume at this stage that a time period is one year, and that the simple yield to maturity is quoted at an annualized rate, like 0.07 or 7 percent. The simple yield can be calculated easily enough: it is that discount rate which equates the bond's price to the present value of its final payment. For example, write the price at time $t$ of an $m$-year bond with a face value of $\$ 1$ as $P_{m t}$. Then, the simple yield $Y_{m t}$ satisfies

$$
P_{m t}=\frac{1}{\left(1+Y_{m t}\right)^{m}}
$$

I will use the term gross yield to mean one plus the simple yield. If the simple yield is 7 percent, then the gross yield is 1.07 .

It is often more convenient to work with the continuously compounded, or log, yield to maturity which is easily calculated as the natural $\log$ of the gross yield. ${ }^{4}$ For realistic yield levels, the difference between the simple yield and the continuously compounded yield is small but not negligible: $\log (1.07)=0.068$, for example.

The continuously compounded yield on a bond has a straightforward relation to the bond's log price. By taking logs of equation (1).

$$
p_{m t}=-m y_{m t}
$$

where $p_{m t} \equiv \log \left(P_{m t}\right)$ is the $\log$ bond price and $y_{m t} \equiv \log \left(1+Y_{m t}\right)$ is the continuously compounded yield. For a bond with a face value of $\$ 1$, the log of the bond price is minus $m$ times the continuously compounded yield. It follows that maturity $m$ measures the proportional change in the price of a zero-coupon bond when the bond's continuously compounded yield changes by one percentage point. A 5-year zero-coupon bond will lose only 5 percent of its value when its continuously compounded yield rises by 1 percentage point, whereas a 30-year zero-coupon bond will lose 30 percent of its value. ${ }^{5}$ The remainder of this article will work with continuously compounded zerocoupon bond yields and will refer to them simply as "yields". 6

If a bond is sold before it matures, an investor receives a holding-period return. Unlike the yield to maturity, the holding-period return is not known in advance because it depends on the uncertain price at which the bond can be sold. If the bond's yield 
happens to remain unchanged over the holding period, then the holding-period return equals the initial yield. If the bond's yield rises during the holding period, however, the holding-period return is less than the initial yield while if the yield falls the holdingperiod return is greater than the initial yield.

To understand this, consider the case where a zero-coupon bond is held for one year. Then, the log holding-period return is just the change in the bond's log price during that year. (For other holding periods, it is the change in the log price divided by the number of years in the holding period to express the return at an annual rate.) We can use equation (2) to rewrite this in terms of yields. Writing $r_{m, t+1}$ for the log one-year return on a bond purchased with maturity $m$ in year $t$ and sold with remaining maturity $m-1$ in year $t+1$, we have

$$
r_{m, t+1}=p_{m-1, t+1}-p_{m t}=y_{m t}-(m-1)\left(y_{m-1, t+1}-y_{m t}\right) .
$$

Thus, the log one-year return is the initial yield, minus the change in the yield during the year the bond is held times the maturity of the bond when it is sold, $m-1$. If no change in yield occurs, then the initial yield is the same as the one-year return.

Equation (3) relates the one-year $\log$ bond return, the log bond yield today, and the $\log$ bond yield at the end of the year. But of course the $\log$ bond yield at the end of the year depends in the same way on the log bond return in the following year and the $\log$ bond yield two years ahead. By repeatedly substituting out future bond yields, one can show that the log bond yield is an unweighted average of one-year log returns on the bond over the course of its life. When returns vary over time, the yield will not generally equal any particular return in the average; this is another way to understand the difference between yields and holding-period returns.

Yields and one-year returns on long-term bonds are often measured relative to the yield on a one-year bond. (For a one-year bond only, the yield equals the one-year return on the bond.) The difference between the long-term yield and the short yield is known as the yield spread; the difference between the one-year return on a long bond and the short yield is known as the excess return. Subtracting the one-year yield from both sides of equation (3), it is easy to see that the excess return is just the yield spread less $(m-1)$ times the change in the long bond yield. 
Yields can be summarized in a plot of yields to maturity against maturity for different bonds on a given date. This plot is known as the yield curve. Figure 1 shows some representative postwar U.S. Treasury yield curves for different dates, taken from McCulloch and Kwon (1993). The yield curve is normally upward-sloping, but it can be downward-sloping ("inverted"), hump-shaped, or even trough-shaped ("inverted hump-shaped"). Yield spreads, therefore, are normally positive but become negative when the yield curve is inverted and may have mixed signs when the yield curve is hump-shaped or inverted hump-shaped.

Over time, the short-term yields at the left of Figure 1 move more than the longterm yields at the right of the figure. But long yields do vary, and as shown by equation (3) small movements in long yields produce big changes in long bond prices and volatile returns on long bonds. This is illustrated by Table 1, which reports unconditional sample means and standard deviations (in parentheses) for several term structure variables over the period 1952-1991.

Table 1 uses monthly data, so the basic time unit is 1 month. All the relations discussed above and expressed algebraically in equations (1), (2), and (3) continue to hold with this change in the time unit, provided that one measures yields and returns per month instead of per year. To keep the units in Table 1 familiar, however, the data are measured in annualized percentage points; that is, the natural monthly variables are multiplied by 1200 .

The variable in the first row of Table 1 is the excess return on an $m$-month zerocoupon bond held for one month, over a one-month Treasury bill. The mean excess return is positive and rising with maturity at first, but it starts to fall at a maturity of one year and is actually negative for 10-year zero-coupon bonds. This pattern may seem surprising, since long bonds normally offer higher yields than one-month bills, as shown by the positive mean yield spread in the third row of Table 1. One can understand the pattern by breaking the excess return into its two components: the yield spread between $m$-period and one-period bonds, and $-(m-1)$ times the change in yield on the $m$-period bond. Bond yields rose during the sample period, as shown by the positive mean yield change in the second row of Table 1, and this caused capital losses on long zero-coupon bonds which outweighed the higher yields offered by these bonds.

The standard deviation of excess long bond returns, shown in parentheses in the first row of Table 1 , rises rapidly with maturity even though the standard deviation of 
yield changes, shown in parentheses in the second row of Table 1, falls with maturity. As one would expect from equation (3), the standard deviation of the excess return is roughly $(m-1)$ times the standard deviation of the yield change. ${ }^{7}$

One other concept is useful in thinking about the term structure. If an investor can freely buy and sell (take positive and negative positions in) bonds of different maturities, then the investor can guarantee an interest rate on a fixed-income investment to be made in the future. ${ }^{8}$ To do this, the investor buys zero-coupon bonds maturing on the desired maturity date, and sells zero-coupon bonds maturing on some earlier date at which the investment is to commence. The sizes of the positive and negative positions are chosen so that no net investment need be made today; when the negative position matures the investor must pay the face value of the bonds in the negative position, and when the positive position later matures, the investor gets back the face value of the bonds in the positive position. The yield to maturity on this investment is called a forward rate. As with yields, one can define a simple and a continuously compounded forward rate. Here I work with the continuously compounded forward rate.

There is a different forward rate for every pair of maturity dates for the underlying positive and negative bond positions; the instantaneous forward rate, the limit as the two maturity dates approach one another, is of particular interest. The relation between a yield to maturity and the instantaneous forward rate at that maturity is analogous to the relation between marginal and average cost. The yield to maturity is the average cost of borrowing for $m$ periods, while the forward rate is the marginal cost of extending the time period of the loan. ${ }^{9}$ The yield to maturity can therefore be written as an average of all the forward rates out to maturity $m$.

Figure 2 illustrates the relation between the instantaneous forward rate curve (the dashed line) and the yield curve (the solid line). The forward rate curve lies above the vield curve when the yield curve is upward-sloping, and below it when the yield curve is downward-sloping. The two curves cross when the yield curve is flat. These of course are the standard properties of marginal and average cost curves.

\section{The expectations hypothesis of the term structure}

An investor who buys a zero-coupon bond knows with certainty that its price at maturity will equal its face value. This means that any unexpected price change that may occur in the near future must be compensated by opposite price changes in the more distant future to bring the price back to face value on the maturity date. 
The variation in nominal returns on a given bond must therefore be negatively serially correlated and hence forecastable. But this argument does not rule out the possibility that excess returns on long bonds over short bonds might be unforecastable.

To illustrate this possibility, consider an investor who faces a 4 percent yield on a one-year bond and a 7 percent yield on a 30 -year bond. A naive investor might believe that the 30-year bond is the superior investment because its yield is 3 percent higher. But this ignores the fact that the 1-year yield is a known return over 1 year, while the 30 -year yield is a known return over 30 years; the two cannot be directly compared because they refer to different horizons.

A more sophisticated investor will recognize that if a bond is sold before it matures, then the holding-period return may not equal initial yield to maturity. In our numerical example, if the 30-year bond is sold after 1 year, it will have a 7 percent return and a 3 percent excess return only if its yield remains unchanged at 7 percent. Alternatively, the 1-year return on the two bonds might be the same if the price of the 30-year bond rises during the year by 4 percent instead of the 7 percent implied by its yield. This smaller price increase will occur if the yield on the 30-year bond rises from 7 percent to 7.1 percent. ${ }^{10}$

Similarly, over 30 years a strategy of rolling over 1-year bonds will have an average return of 4 percent only if 1-year yields remain unchanged at 4 percent on average. The sequence of 1-year bonds might deliver the same return as a single 30 -year bond if 1 -year yields over the next 30 years average 7 percent. Since the first 1 -year yield in the average is only 4 percent, this requires that the remaining 291 -year yields average 7.1 percent, slightly higher than today's 7 percent 30 -year yield and much higher than today's 4 percent 1 -year yield. ${ }^{11}$

The pure expectations hypothesis of the term structure is the theory that interest rates are expected to move in exactly this way, to equalize expected returns on shortand long-term investment strategies. The expectations hypothesis is the slightly weaker proposition that the difference between the expected returns on short- and long-term investment strategies is constant, although it need not be zero as required by the pure hypothesis. ${ }^{12}$ In the numerical example, the 30 -year bond might have an average return 3 percentage points higher than the 1 -year bond. In this case a 3 percent yield spread would not require any expected change in interest rates, but a yield spread higher or lower than 3 percent would be associated with expected interest rate movements.

To make these hypotheses testable one must state how expectations are formed; I 
shall assume that expectations are rational. ${ }^{13}$ Both versions of the expectations hypothesis then imply that excess returns on long bonds over short bonds are unforecastable, with a zero mean in the case of the pure expectations hypothesis.

For either theory to hold, yields must tend to move through time to offset initial yield differences across bonds. Thus both hypotheses have strong implications for the relation between yield spreads and future movements in interest rates. The pure expectations hypothesis says that whenever a long bond yield exceeds a short yield, the yield on the long bond subsequently tends to rise over the life of the short bond; this generates expected capital losses on the long bond which offset the current yield advantage. From equation (3) the one-period excess return on an $m$-period bond is the yield spread less $(m-1)$ times the change in the yield on the long bond, so the expected increase in the long yield must be exactly $1 /(m-1)$ times the current yield spread.

The pure expectations hypothesis also says that whenever a long bond yield exceeds a short yield, short yields tend to rise to equate returns over the life of the long bond; the average short rate over the life of the long bond must equal the current yield on the long bond, which requires that the difference between the average short rate over the remaining $m-1$ periods and the current short rate must be $m /(m-1)$ times the current yield spread. The expectations hypothesis implies similar tendencies whenever the spread between a long bond yield and a short bond yield is unusually high.

These theories have an implication that is counterintuitive for many of those studying them for the first time. When long rates are unusually high relative to short rates, long rates do not decline to restore the usual yield curve, as one might suppose. Instead long rates tend to rise; the yield spread falls only because short rates rise even faster.

The pure expectations hypothesis also implies that instantaneous forward rates equal expected future short rates; for the expectations hypothesis, the two are equal after being adjusted by a constant. Thus, both theories imply that one can read investors' expectations about future interest rates off the forward rate curve.

\section{Some empirical evidence}

I now summarize the empirical evidence on the validity of these theories about the term structure. First I ask whether the excess return on long bonds over short bonds has a zero mean, as required by the pure expectations hypothesis. Then I ask whether the deviation of the excess return from its mean is unforecastable, as required by both 
forms of the expectations hypothesis.

To answer the first question, whether excess long bond returns are zero on average, recall that the first row of Table 1 shows the sample mean and standard deviation of the excess monthly return on $m$-month zero-coupon bonds over one-month bills in the period 1952-91. As I noted earlier, the sample mean excess return is positive and rising with maturity at first, but around one year it begins to decline with maturity and actually becomes negative for 10-year zero-coupon bonds. The precision with which the sample mean estimates the true mean excess return depends on the standard deviation of excess returns, which rises rapidly with maturity. The usual formula for the standard error of the mean of a serially uncorrelated random variable is the variable's standard deviation divided by the square root of the sample size ( 469 months). For $m=2$ this standard error is only 0.03 percent, whereas for $m=120$ it is 1.70 percent. Thus, the pattern of mean returns is imprecisely estimated at long maturities. There is strong evidence that lengthening bond maturity increases average returns at maturities of a few months, but no clear evidence for higher or lower average returns at maturities beyond a year or so.

To answer the second question, whether excess long bond returns vary predictably through time, one can look at the relation between yield spreads and future interest rate movements. If the expectations hypothesis holds, then excess returns on long bonds over short bonds must be unforecastable over the life of the short bond, so high yield spreads must be associated with rising long yields. The first row of Table 2 reports the slope coefficients (with standard errors underneath in parentheses) from a series of regressions of long rate changes on a constant and the long-short yield spread. In these regressions, the spread is scaled so that if the expectations hypothesis holds the slope coefficient should be one. In fact all but one of the slope coefficients are negative; all are significantly less than one, and some are significantly less than zero. When the long-short yield spread is high, the long yield tends to fall, amplifying the yield differential between long and short bonds, rather than rising to offset the yield spread as required by the expectations hypothesis. ${ }^{14}$

This is exactly the behavior noted by Macaulay (1938), in a classic work on the movements of asset prices in the late 19 th and early 20 th centuries. Macaulay wrote (p. 33): "The yields of bonds of the highest grade should fall during a period in which short-term rates are higher than the yields of the bonds and rise during a period in which short-term rates are lower. Now experience is more nearly the opposite." The 
fact that this finding appears in the late 20th century as well as in Macaulay's data is particularly impressive.

One difficulty with the regression in the first row of Table 2 is that it is extremely sensitive to measurement error in the long-term interest rate (Stambaugh, 1988). Since the long rate appears both in the regressor with a positive sign (as part of the yield spread) and in the dependent variable with a negative sign (as part of the change in the long yield), measurement error would tend to produce the negative signs found in Table 2. However, Campbell and Shiller (1991) point out that this can be handled by using instrumental variables regression where the instruments are correlated with the yield spread but not with the bond yield measurement error. They try a variety of instruments and find that the negative regression coefficients are quite robust.

The regressions estimated in the first row of Table 2 emphasize the short-run behavior of long-term interest rates. But the expectations hypothesis also restricts the long-run behavior of short-term interest rates. If the expectations hypothesis holds, then the excess return on a long bond over a sequence of short bonds must be unforecastable over the life of the long bond, so high yield spreads must be associated with rising short-term interest rates. There is much more truth in this implication of the expectations hypothesis.

The second row of Table 2 reports slope coefficients (with standard errors underneath in parentheses) for regressions of long-run changes in short-term interest rates onto a constant and the yield spread. Again, the regression is scaled so that if the expectations hypothesis holds, then the slope coefficient would be one. ${ }^{15}$ For small $m$ the coefficients are smaller than one but significantly positive; up to a year or so they decline with $m$, becoming insignificantly different from zero. Beyond one year the coefficients increase and at 10 years the coefficient is even significantly greater than 1 . Thus the second row of Table 2 shows that yield spreads have forecasting power for short rate movements at horizons of 2 or 3 months, and again at horizons of several years. Around 1 year, however, yield spread variation seems almost unrelated to subsequent movements in short rates.

\section{Further interpretation}

Table 2 seems self-contradictory. The results in the first row (that yield spreads don't forecast short-run changes in long yields) contradict the expectations hypothesis of the term structure. Yet the results in the second row (that yield spreads do forecast 
long-run changes in short yields) offer some support for the expectations hypothesis, at least at very short and very long maturities. What are we to make of these mixed results?

To resolve this contradiction, recall that the yield spread equals the known return to maturity on a long bond, less the known 1-period return on a short bond. If the yield spread is high, then either the long bond must have a higher return over its life than a series of short bonds, or short-term interest rates must rise over the life of the long bond, or some combination of the two must occur. Rational expectations of returns and interest rates must reflect this identity (as must any plausible expectations, whether rational or not). Thus, a high yield spread must correspond to rational expectations of high returns on long bonds, increases in interest rates, or some mixture of the two. The expectations hypothesis says that investors never rationally expect unusually high or low returns on long bonds, so that the yield spread reflects only rationally expected movements in short rates. In this case, regressions of appropriately scaled changes in long and short rates onto the yield spread will give a coefficient of one. In general, however, the yield spread will reflect changing rational expectations of both excess long-bond returns and future short-term interest rates.

In a regression of long rate changes onto the yield spread, changing rational expectations about excess long-bond returns act like measurement error that appears positively in the regressor and negatively in the dependent variable; a small measurement error of this sort can change the sign of the regression coefficient from positive to negative.

In a regression of short rate changes onto the yield spread, however, changing rational expectations about excess long-bond returns act like measurement error that appears only in the regressor; this kind of measurement error biases the coefficient down towards zero but does not change the sign of the coefficient. ${ }^{16}$ The magnitude of the bias depends on the relative variances of the two components of the spread. For a given variance of rationally expected excess long-bond returns, there will be less downward bias when the variance of rationally expected changes in short rates is large - that is, when investors are well-informed about future movements in short rates. Consistent with this story, Mankiw and Miron (1986) have pointed out that interest rate movements were more predictable before the founding of the Federal Reserve in 1913 and the downward bias appears to be smaller in that period. Balduzzi, Bertola, and Foresi (1993) and Rudebusch (1994) argue that contemporary Federal Reserve 
operating procedures lead to predictable interest rate movements in the very short run and the very long run, but tend to smooth away predictable movements in the medium run. This may explain why the coefficients in the second row of Table 2 are smallest at horizons around one year.

If there are periods when rationally expected returns are higher on long bonds than on short bonds, why don't investors buy long bonds and sell short bonds until the difference in expected returns is eliminated? Two main explanations have been suggested. First, it is possible that investors do not have rational expectations; they do not perceive the profit opportunities that are documented in Table 2. Many of the term structure models of the 1960's, including the influential work of Meiselman (1962), did not impose rational expectations and therefore allowed for the possibility that systematic profit opportunities could exist. Froot (1989) uses survey data to argue for this explanation. ${ }^{17}$

Second, the predictable variation in excess returns shown in Table 2 can only be exploited by taking on risk. A dynamic investment strategy that goes long when the yield curve is steep and short when the yield curve is flat has historically produced superior returns on average; but in any particular year it can lose money as Orange County, California discovered most recently in 1994. It is possible that the superior average returns of the dynamic investment strategy are simply compensation for its risk; equivalently, it is possible that the yield spread signals higher long-bond excess returns because long-bond risk is high when the yield spread is high. To make this explanation complete, one must identify the underlying sources of variation in risk and there is much work in the modern finance tradition that attempts to do this. Following the seminal work of Cox, Ingersoll, and Ross (1985), for example, many authors have developed term structure models in which interest rate volatility and required excess bond returns move together; these models fit some aspects of the data but unfortunately do not fully explain the observed predictable variation in expected excess returns.

\section{Monetary Policy and the Bond Market in Spring 1994}

The spring of 1994 was a dramatic time for the U.S. bond market. The Federal Reserve had lowered short-term interest rates repeatedly in the period 1990-92 to combat weakness in the economy and had held short rates down throughout 1993. But in early February 1994 the Fed raised its target federal funds rate, the overnight rate 
paid by a bank that borrows reserves to a bank that lends them, from 3 percent to 3.25 percent. This move was rapidly followed by two more quarter-point increases in March and April, and a half-point increase in May accompanied by a half-point increase in the discount rate, the interest rate the Fed charges when it lends reserves to banks. Thus in four months the federal funds rate - the interest rate at the extreme short end of the yield curve - rose by about 1.25 percentage points. There have been several further increases in the federal funds rate since then, but it is impossible to keep the discussion entirely current and I will concentrate here on events through the end of May 1994.

Many commentators and market participants, not to mention the policy makers at the Federal Reserve, were surprised by the effects of these policy changes on longerterm bond yields. These effects are illustrated in Figure 3, which shows the average zero-coupon yield curves in five different periods in early 1994. The solid line is the average yield curve from January 1 to February 3, the period before the first shortrate increase. At that time the federal funds rate was about 3 percent, the 6 -month zero-coupon yield was under 3.5 percent, the 5 -year zero-coupon yield was just over 5 percent, the 10-year yield was almost 6 percent, and the 30 -year yield was almost 6.5 percent. This represents a steep yield curve by historical standards: The spread between the 10-year zero-coupon yield and the short rate was about 3 percent, more than twice the average for the period 1952-91 shown in Table 1. The long-dashed line shows the average yield curve from February 4 to March 21, the period after the first short-rate increase and before the second increase; the dotted-dashed line shows March 22 to April 15, the period between the second and third increases; the short-dashed line shows April 18 to May 16, the period between the third and fourth increases; and the dotted line shows May 17 to May 24, the brief period between the last short-rate increase and the end of the data. Figure 4 is constructed in the same manner as Figure 3 , but it shows implied instantaneous forward rate curves rather than zero-coupon yield curves. 18

To understand why the behavior of the bond market was surprising, recall that normally long yields are less variable than short rates. An increase in the short rate is typically associated with a smaller increase in the long rate. In spring 1994, however, the first Fed policy move drove up the federal funds rate by a quarter of a percentage point but the 6-month, 5-year, and 10-year yields each rose by half a point and the 30 -year yield rose by about a quarter point. The response to the second policy move was similar. From January to early April, then, the short and long ends of the yield 
curve both rose by half a percentage point while the middle of the yield curve rose by a full percentage point.

Later in the spring of 1994, the bond market reacted less violently to the Fed's policy moves. The third short-rate increase in April had only a small effect on the 30-year zero-coupon yield and it raised the 6-month, 1-year, and 5-year yields about one-for-one. It had little effect on forward rates. The fourth short-rate increase in May was followed by small decreases in zero-coupon yields of all maturities, and large declines in forward rates.

How can we understand these shifts in the yield curve? One interpretation emphasizes the changing expectations of bond market participants about the future path of interest rates. During the early 1990s, the Federal Reserve under Chairman Greenspan established a reputation for gradualism, lowering short rates repeatedly in quarterpoint steps. Hence, the first rise in the federal funds rate in February led investors to expect further moves in the same direction. They increased their expectations of future short rates, reflected in forward rates, by more than 25 basis points; this made the yield curve steeper. According to this view, the rapid series of rate increases in March, April, and May simply shows that investors were well-informed about the likely course of Fed policy (although not perfectly informed, since forward rates continued to respond to all the Fed's actions except that in April).

The problem with this view is that forward rates rose not only at maturities of a few months but at 5- and 10-year maturities as well. If investors interpreted the Fed's actions as revealing a stronger distaste for inflation, they should have revised downwards their expectations of future inflation. Given stable expectations of future real interest rates, this should have driven 5- and 10-year nominal forward rates down rather than up. ${ }^{19}$ It is possible that investors instead believed that the Fed acted in response to private information about incipient inflation, but if the Fed's anti-inflationary actions were at all credible they should have forestalled increases in investors' inflation expectations 5 or 10 years ahead.

An alternative view is that the increases in 5-and 10-year zero-coupon bond yields were driven in part by increases in required excess returns on long bonds. Required excess returns may have gone up because of increases in risk, manifested in greater bond-market volatility but attributable ultimately to uncertainty about Fed policy, or because losses incurred by highly leveraged bond traders increased the effective riskaversion of some market participants. One piece of evidence which supports this view 
is that 5-and 10-year forward rates dropped by almost a full percentage point after the Fed policy move in mid-May. That move was accompanied by an unusual Fed press release announcing the Fed's belief that further policy moves would be unnecessary in the short term.

Under the expectations view, a policy move that does not change expected future interest rates should not move forward rates, whereas under the required-returns view, forward rates may decline if the move reduces uncertainty about future policy. It is striking that by the end of May, 5- and 10-year forward rates had nearly returned to their level in January (they were within 30 basis points). While it is possible that this reflects an upward shift in expected future rates followed by an equally large downward shift, it seems more likely that bond yields were affected by a temporary change in required excess bond returns. This story is consistent with the evidence against the expectations hypothesis of the term structure presented earlier.

\section{Should the Government Borrow Short or Long?}

Growth in U.S. government debt over the past 15 years has helped to revive an old debate over the best way for the government to manage its liabilities. Federal debt held by the public reached a postwar low of less than 30 percent of GDP in the late 1970 s but has now reached 55 percent of GDP and is forecast to be 70 percent of GDP by the end of the century. Federal interest outlays have grown accordingly; they were just over 1 percent of GDP in the 1970s but now exceed 3 percent of GDP and may reach 4 percent of GDP by the end of the century (Congressional Budget Office, 1993). These interest outlays roughly equal the entire federal budget deficit.

In early 1993, the Clinton administration argued that significant reductions in interest costs could be achieved by shortening the average maturity of debt securities. The administration estimated over $\$ 10$ billion in cumulative savings over the period 1994-1998 (Office of Management and Budget, 1993). A few months later, the Treasury announced that it would shift more than $\$ 50$ billion a year of new issues from longerto shorter-term maturities by reducing the issue of 30 -year bonds and eliminating the issue of 7 -year notes, replacing these securities with 2- and 3-year notes and Treasury bills. This is a striking shift in policy; since the late 1970s, the Treasury had gradually increased the average maturity of the debt from three to six years, but this trend will now be reversed. However, the average maturity of the debt is forecast to fall only to 
about five years by 1998 .

The summary statistics about the term structure presented earlier can help to answer whether going short is likely to reduce average interest costs, whether it will increase the risks of financing the debt, and more generally how one should think about the choice of a debt management policy.

Is short borrowing cheap?

Table 1 shows that over the period 1952-91 the average monthly holding-period return on 12-month Treasury bills exceeded the average return on 1-month bills by about 0.9 percent, but longer-term zero-coupon bonds offered lower returns. This suggests that shortening the maturity of Treasury bills reduces average interest costs, but shortening the maturity of long-term debt increases average interest costs. Many commentators, however, do not rely on historical average returns but instead look at historical average yield spreads. Table 1 shows that in 1952-91 ten-year zero-coupon bond yields were on average about 0.6 percent above one-year yields. This suggests modest savings from shortening the average maturity of long-term government debt.

Which is the best number to use: the average return or the average yield spread? If one assumes that the long-rum average change in the short rate is zero, so that there is no long-run tendency for interest rates to drift up or down, then these two numbers should be equal in the long run. But in an unusual sample period where investors are surprised by interest rate increases, the sample average excess return on long bonds will be below its true long-run mean. Similarly, in an unusual period where interest rate increases are expected to occur, the sample average yield spread will reflect these increases and will be above its true long-run mean. It seems plausible that the period 1952-91 satisfies both these conditions: that is, investors expected interest rates to rise, but the rise was greater than expected. In such a period, the sample average yield spread is an upward-biased measure of the interest savings that can be achieved by shortening the debt, and the average excess long bond return is a downward-biased measure. Overall, the postwar U.S. data do not speak clearly. The government might be able to reduce average interest costs with extremely short-term Treasury bill financing, but there is no strong evidence that the government can cut costs by shortening the maturity of its longer-term debt. ${ }^{20}$

Even if there is little to be gained from permanently shortening the maturity of the public debt, the Treasury might save by shortening debt maturity when the yield 
curve is particularly steep (as it has been in the early 1990s) and lengthening maturity when the yield curve is flat or inverted (as it was in the early 1980s). The evidence of Table 2 is that yield spreads do forecast excess returns on long-term bonds. This means that a naive investor who goes long when long bond yields are relatively high (thus ignoring the difference between yields and holding returns) does in fact earn higher average returns. Similarly, the Treasury can reduce the average cost of its debt by going short when the yield curve is steep and long when the yield curve is flat.

A government may also be able to use debt management to reduce interest costs in circumstances where it has superior information about the likely future path of interest rates. In the early 1980s in Britain, for example, the Conservative government of Margaret Thatcher faced extremely high short- and long-term nominal interest rates. As in the United States at that time, inflation had risen during the 1970s and long bond yields reflected investors' fears that inflation would continue. Anti-inflationary monetary policy had also driven up short rates. The Thatcher government introduced index-linked bonds, whose nominal coupon payments and face value automatically increase with the price level; these bonds were at first issued in limited quantities but now account for over 10 percent of the British government debt (Brown and Schaefer, 1994). One rationale for this policy was that the government felt more confident about its anti-inflationary resolve than investors did. Rather than pay an inflation premium in long-term nominal debt, the government offered inflation protection to investors. This policy reduced the British government's interest costs during the 1980s; longterm nominal bonds gave investors very high returns for most of the decade as inflation and nominal interest rates fell, while index-linked bonds offered mediocre returns as real interest rates increased.

\section{Is short borrowing risky?}

Opponents of short-term borrowing often argue that it would increase the risks of debt management. While short-term borrowing might be cheaper on average, it would be expensive when short-term nominal interest rates are high. Since long-term bond yields are more stable than short-term yields, the argument runs, long-term borrowing is less risky for the government. 21

There are two problems with this argument. First, it confuses bond yields with bond returns. To measure the risks of an investment or debt management policy, one should look at the returns on the policy measured over some uniform horizon. 
Short rates equal short-bond returns at short horizons, and long yields equal long-bond returns at long horizons, so they are not directly comparable. Second, the argument confuses nominal returns with real returns - the latter, presumably, being of primary concern to the government. In nominal terms the volatility of returns depends on the horizon, with short bonds offering known returns at short horizons and long bonds offering known returns at long horizons. But in real terms, it turns out that long-bond returns are more volatile than short-bond returns at all horizons.

To understand the point intuitively, consider what happens to the government's financial position if its debt is financed long and there is a permanent increase in the inflation rate. The government's future nominal liabilities do not change, but inflation now erodes the real value of the government's fixed nominal payments more rapidly so the government's financial position is improved. This is reflected immediately in a decline in the market value of the government debt. Conversely, if inflation falls the real market value of the government debt rises. Thus the government is exposed to the risk that inflation will change. If the government has issued short-term debt, on the other hand, an increase in inflation drives up the government's nominal interest cost; this roughly offsets the faster erosion of the nominal debt by inflation, leaving the government's real position unaffected. The difficulty with popular discussion is that it usually concentrates on nominal interest costs, ignoring the important role of inflation and the distinction between real and nominal returns.

While the risks of short-term borrowing are commonly exaggerated, several caveats are worth noting. First, standard deviation is in general an inadequate measure of risk; a more satisfactory analysis would measure risk within the context of an asset pricing model. Second, changes in nominal interest costs may have political effects even if real interest costs are constant. Standard budget deficit figures do not correct for the effects of inflation, and these figures are important in public perception and political arrangements such as the 1990 budget agreement. Third, if the government wishes to limit the variability of real returns on its debt over long horizons, it can do so most effectively with long-term indexed bonds of the type issued in Britain. Such bonds guarantee investors a fixed long-run real rate of return regardless of variations in inflation and short-term real interest rates.

\section{Other considerations in the conduct of debt management}

The term-structure literature is useful in judging the effects of debt management 
on interest costs, but the choice of a debt managernent policy involves some broader issues. From the beginning it is important to keep in mind that there are circumstances under which debt management policy does not matter at all. This apparently startling idea is easiest to grasp if one thinks about the analogy between the government and a corporation. Economists are used to the Modigliani-Miller theorem, the proposition that a firm's investment policy determines its value regardless of its financial policy. The value of a firm is the value of the firm's cash flows in each state multiplied by the state price for that state; thus corporate financial policy cannot affect value if cash flows and state prices are fixed. The Modigliani-Miller theorem breaks down if financial policy affects cash flows in some states (because of taxes or bankruptcy costs) or if it affects state prices (because markets are incomplete or investors have imperfect information).

The analogous irrelevance theorem for the government says that debt management policy has no real effects, given spending policy, if markets are complete and the government can levy nondistortionary taxes. In this case, a debt management policy that results in losses for the government in a particular state need not change private-sector consumption in that state. The government can satisfy its budget constraint by raising nondistortionary taxes when it suffers losses, and the private sector can pay the taxes from the proceeds of its bond holdings. In this situation, average interest costs and the variability of interest costs across states are of no real importance. ${ }^{22}$

These conditions for irrelevance of debt management policy - particularly the requirement that nondistortionary taxes are available - are too stringent to be realistic. Accordingly a number of authors have explored debt management policy in models where it may matter. One line of argument, initiated by Barro (1979) and continued by Bohn $(1988,1990)$, is that debt should be used to equate the marginal welfare cost of distortionary taxation across states. In this type of model, one can think of the government's optimal debt management policy as minimizing average risk-adjusted interest costs. The evidence from the term-structure literature is a necessary input to this process.

The term-structure literature, however, takes the historical behavior of interest rates as given and does not ask how debt management policy might affect interest rates. Some authors have alleged that shifts in relative supplies of short- and long-term bonds have large effects on their yields and expected returns (Agell, Persson, and Friedman, 1992). The evidence for the supply effect is mixed, but if it is important then any 
large-scale attempt by the Treasury to save money by changing debt maturity would tend to be self-defeating. If the Treasury shifted to short-term financing, for example, the greater supply of Treasury bills would drive down the price of bills and reduce or eliminate the sought-after savings.

Other authors emphasize that debt-management policy can change nominal interest rates by changing the expectations of investors regarding inflation (for a recent discussion see Missale and Blanchard, 1994). Governments with long-term nominal debt have an incentive to inflate to erode the real value of their obligations. Understanding this, investors may expect higher inflation when debt is long-term and nominal than when it is short-term or indexed. This argument has its limitations. It assumes that a single authority sets both fiscal and monetary policy, or at least that fiscal considerations influence the monetary authority; and it ignores the fact that holders of long-term nominal bonds may exert anti-inflationary pressure within a democratic political system. However, to the extent that this view holds true, it would imply that the British government's use of indexed debt in the early 1980s not only reduced the government's costs as interest rates fell; it actually helped to reduce interest rates by increasing the credibility of the government's anti-inflationary policy.

This brief review suggests that shortening the maturity of the government debt, or issuing indexed debt, has several potential advantages. First, the government can reduce its average interest costs if it shortens maturity when the yield curve is steep (as it has been in the early 1990s). Second, shortening maturity or issuing indexed debt reduces the variability of the real returns on government debt, and therefore reduces the variability of the government's real financing costs. Finally, shortening maturity or issuing indexed debt may lower inflationary expectations if it improves the credibility of anti-inflationary monetary policy.

I am grateful to Sydney Ludvigson and Chunsheng Zhou for able research assistance, and to Glenn Rudebusch, David Wilcox, David Zervos, and the editors of the Journal of Economic Perspectives for many helpful comments. 


\section{References}

Agell, Jonas, Mats Persson, and Benjamin M. Friedman, 1992. Does Debt Management Policy Matter?, Oxford University Press: Oxford.

Balduzzi, Pierluigi, Giuseppe Bertola, and Silverio Foresi, 1993, "A Model of Target Changes and the Term Structure of Interest Rates", NBER Working Paper No. 4347 .

Barro, Robert J., 1979, "On the Determination of Public Debt", Journal of Political Economy 87, 940-971.

Bohn, Henning, 1988, "Why Do We Have Nominal Government Debt?", Journal of Monetary Economics 21, 127-140.

Bohn, Henning, 1990, "A Positive Theory of Foreign Currency Debt", Journal of International Economics 29, 273-292.

Brown, Roger H. and Stephen M. Schaefer, 1994, "The Term Structure of Real Interest Rates and the Cox, Ingersoll, and Ross Model", Journal of Financial Economics $35,3-42$.

Campbell, John Y., 1986, "A Defense of Traditional Hypotheses About the Term Structure of Interest Rates". Journal of Finance 41, 183-193.

Campbell, John Y. and John Ammer, 1993, "What Moves the Stock and Bond Markets? A Variance Decomposition for Long-Term Asset Returns", Journal of Finance 48, $3-37$.

Campbell, John Y., Andrew W. Lo, and A. Craig MacKinlay, 1995, The Econometrics of Financial Markets, forthcoming Princeton, NJ: Princeton University Press.

Campbell, John Y. and Robert J. Shiller, 1991, "Yield Spreads and Interest Rate Movements: A Bird's Eye View", Review of Economic Studies 58, 495-514.

Congressional Budget Office, 1993, Federal Debt and Interest Costs, Washington, DC.

Cox, John C., Jonathan E. Ingersoll, and Stephen A. Ross, 1981, "A Reexamination of Traditional Hypotheses about the Term Structure of Interest Rates", Journal of Finance 36, 769-799.

Cox, John C., Jonathan E. Ingersoll, and Stephen A. Ross, 1985, "A Theory of the Term Structure of Interest Rates", Econometrica 53, 385-408.

Estrella, Arturo and Gikas A. Hardouvelis, 1991, "The Term Structure as a Predictor of Real Economic Activity", Journal of Finance 46, 555-576.

Fama, Eugene F., 1984, "The Information in the Term Structure", Journal of Financial Economics 13, 509-5210.

Fama, Eugene F., 1990, "Term-Structure Forecasts of Interest Rates, Inflation, and Real Returns", Journal of Monetary Economics 25, 59-76.

Fama, Eugene F., and Robert R. Bliss, 1987, "The Information in Long- Maturity Forward Rates", American Economic Review 77, 680-692. 
Fama, Eugene F. and Kenneth R. French, 1989, "Business Conditions and Expected Returns on Stocks and Bonds", Journal of Financial Economics 25, 23-49.

Fisher, Mark, Douglas Nychka, and David Zervos, 1994, "Fitting the Term Structure of Interest Rates with Smoothing Splines", unpublished paper, Federal Reserve Board and North Carolina State University.

Froot, Kenneth A., 1989, "New Hope for the Expectations Hypothesis of the Term Structure of Interest Rates", Journal of Finance 44, 283-305.

Hicks, John R., 1939, Value and Capital: An Inquiry into Some Fundamental Principles of Economic Theory, Oxford: Clarendon Press.

Kane, Edward J., 1970, "The Term Structure of Interest Rates: An Attempt to Reconcile Teaching with Practice", Journal of Finance 25, 361-374.

Keim, Donald B. and Robert F. Stambaugh, 1986, "Predicting Returns in the Stock and Bond Markets", Journal of Financial Economics 17, 357-390.

Lutz, F.A., 1940, "The Structure of Interest Rates", Quarterly Journal of Economics $55,36-63$.

Macaulay, Frederick R., 1938, Some Theoretical Problems Suggested by the Movements of Interest Rates, Bond Yields, and Stock Prices in the United States Since 1856. New York: National Bureau of Economic Research.

Mankiw, N. Gregory and Jeffrey A. Miron, 1986, "The Changing Behavior of the Term Structure of Interest Rates", Quarterly Journal of Economics 101, 211-2210.

McCulloch, J. Huston, 1971, "Measuring the Term Structure of Interest Rates", Journal of Business 44, 19-31.

McCulloch, J. Huston, 1975, "The Tax-Adjusted Yicld Curve", Journal of Finance 30, $811-830$.

McCulloch, J. Huston and Heon-Chul Kiwon, 1993, "US Term Structure Data, 19471991", Ohio State University Working Paper No. 93-6.

Meiselman, David, 1962, The Term Structure of Interest Rates, Englewood Cliffs, N.J: Prentice-Hall.

Melino, Angelo, 1988, "The Term Structure of Interest Rates: Evidence and Theory", Journal of Economic Surveys 2, 335-366.

Mishkin, Frederic S., 1990a, "What Does the Term Structure Tell Us About Future Inflation?", Journal of Monetary Economics 25, 77-95.

Mishkin, Frederic S., 1990b, "The Information in the Longer-Maturity Term Structure About Future Inflation", Quarterly Journal of Economics 105, 815-8210. University.

Missale, Alessandro and Olivier J. Blanchard, 1994, "The Debt Burden and Debt Maturity", American Economic Review 84, 309-319. 
Modigliani, Franco and Richard Sutch, 1967, "Debt Management and the Term Structure of Interest Rates: An Empirical Analysis of Recent Experience", Journal of Political Economy 75, 569-589.

Office of Management and Budget, 1993, A Vision of Change for America, Washington, DC.

Rudebusch, Glenn D., 1994, "Federal Reserve Interest Rate Targeting, Rational Expectations, and the Term Structure", unpublished paper, Federal Reserve Bank of San Francisco.

Shiller, Robert J., 1990, "The Term Structure of Interest Rates", in Benjamin M. Friedman and Frank H. Hahn eds. Handbook of Monetary Economics, Amsterdam: North-Holland.

Shiller, Robert J., John Y. Campbell and Kermit L. Schoenholtz, 1983, "Forward Rates and Future Policy: Interpreting the Term Structure of Interest Rates", Brookings Papers on Economic Activity 1, 173-217.

Sill, Keith, 1994, "Managing the Public Debt", unpublished paper, Federal Reserve Bank of Philadelphia.

Stambaugh, Robert F., 1988, "The Information in Forward Rates: Implications for Models of the Term Structure", Journal of Financial Economics 21, 41-70. 


\section{Table 1}

Means and standard deviations of term structure variables

\begin{tabular}{c|ccccccc} 
& \multicolumn{7}{|c}{ Long bond maturity (months) } \\
Variable & 2 & 3 & 6 & 12 & 24 & 48 & 120 \\
\hline & 7 & & & & & & \\
$\begin{array}{c}\text { Excess } \\
\text { return }\end{array}$ & 0.379 & 0.553 & 0.829 & 0.862 & 0.621 & 0.475 & -0.234 \\
& $(0.640)$ & $(1.219)$ & $(2.950)$ & $(6.203)$ & $(11.29)$ & $(19.32)$ & $(36.77)$ \\
\hline & & & & & & & \\
$\begin{array}{c}\text { Change in } \\
\text { yield }\end{array}$ & 0.014 & 0.014 & 0.014 & 0.014 & 0.014 & 0.014 & 0.013 \\
& $(0.591)$ & $(0.575)$ & $(0.569)$ & $(0.546)$ & $(0.486)$ & $(0.408)$ & $(0.307)$ \\
\hline & & & & & & & \\
\hline $\begin{array}{c}\text { Yield } \\
\text { spread }\end{array}$ & 0.196 & 0.324 & 0.569 & 0.761 & 0.948 & 1.141 & 1.358 \\
& $(0.210)$ & $(0.301)$ & $(0.437)$ & $(0.594)$ & $(0.799)$ & $(1.013)$ & $(1.234)$ \\
\hline
\end{tabular}

Source: Author's calculations using estimated monthly zero-coupon yields, 195291, from McCulloch and Kwon (1993). The data are measured monthly, but expressed in annualized percentage points. Each row shows the mean of the variable, with the standard deviation below in parentheses. Excess returns and yield spreads are measured relative to 1-month Treasury bill rates. 


\section{Table 2}

Regression coefficients

\begin{tabular}{c|ccccccc} 
Dependent & \multicolumn{7}{|c}{ Long bond maturity (months) } \\
variable & 2 & 3 & 6 & 12 & 24 & 48 & 120 \\
\hline $\begin{array}{c}\text { Short-run } \\
\text { changes } \\
\text { in long } \\
\text { yields }\end{array}$ & 0.019 & -0.135 & -0.842 & -1.443 & -1.432 & -2.222 & -4.102 \\
\hline $\begin{array}{c}\text { Long-run } \\
\text { changes } \\
\text { in short } \\
\text { yields }\end{array}$ & $0.194)$ & $(0.285)$ & $(0.444)$ & $(0.598)$ & $(0.996)$ & $(1.451)$ & $(2.083)$ \\
\hline
\end{tabular}

Source: Author's calculations using estimated monthly zero-coupon yields, 195291, from McCulloch and Kwon (1993). Each row shows a regression coefficient $\beta$, with the standard error below in parentheses. Each coefficient should be one if the expectations hypothesis holds. The regression in the first row is

$$
y_{m-1, t+1}-y_{m t}=\alpha+\beta\left(y_{m t}-y_{1}\right) /(m-1) \text {, }
$$

where $m$ is long bond maturity in months. The regression in the second row is

$$
\sum_{i=1}^{m-1} y_{1, t+i} /(m-1)-y_{1 t}=\alpha+\beta((m-1) / m)\left(y_{m t}-y_{1 t}\right) .
$$

The standard error in the second row is corrected for serial correlation in the error term of the regression. 


\section{Notes}

1. Melino (1988) and Shiller (1990) are excellent recent surveys of the academic literature. Campbell, Lo, and MacKinlay (1995, chapters 10 and 11) offer a graduatelevel textbook treatment.

2. Actually, theorists often model the prices of real bonds which make known real payments, whereas almost all traded bonds make known nominal and random real payments. This is an important difference; after all, one can always define a numeraire such that any asset's payments are known in advance when they are measured in that numeraire. I shall return to the distinction between real and nominal bonds in discussing the government's choice of debt maturity.

3. Some Treasury bonds issued before 1985 are callable in the last five years before maturity.

4. In equation (1), interest is compounded once a year. If we calculate a yield $Y_{m, n, t}$ on an $m$-year bond assuming that interest is compounded $n$ times a year, we get $P_{m t}=1 /\left(1+Y_{m, n, t} / n\right)^{m n}$. The limit of $Y_{m, n, t}$ as $n$ increases is the continuously compounded or log yield $y m t$.

5. This result does not apply directly to coupon-bearing Treasury bonds. An approximate equivalent of maturity for coupon-bearing bonds is Macaulay's (1938) concept of duration. Duration is the weighted average maturity of the zero-coupon bonds that are packaged together to make a coupon-bearing bond, where the present values of each payment in the package (evaluated using the yield to maturity on the coupon-bearing bond) are the weights. A 30-year Treasury bond with an annual coupon rate of 7 percent and a yield to maturity of 7 percent has a duration of just over 13 years. Such a bond will lose $13 x$ percent of its value when its yield rises by $x$ percentage points, for small $x$. Campbell, Lo, and MacKinlay (1995, chapter 10), Shiller (1990), and Shiller, Campbell, and Schoenholtz (1983) give more details on duration.

6. This approach, which is common in the empirical literature, sidesteps various difficulties to do with Jensen's Inequality. For a discussion of Jensen's Inequality effects see Cox, Ingersoll, and Ross (1981) and Campbell (1986). 
7. This is not an exact equality because the yield change reported is $y_{m, t+1}-y_{m}$ rather than $y_{m-1, t+1}-y_{m t}$, and because variations in the yield spread also contribute to variations in excess returns.

8. Positive and negative investments are normally known as long and short positions; I avoid this terminology here to avoid confusion with long and short maturities.

9. One can show that the $m$-period-ahead instantaneous forward rate $f_{m t}$ is the $m$-period zero-coupon yield plus $m$ times the slope of the yield curve at maturity $m$ : $f_{m t}=y_{m t}+m \partial y_{m t} / \partial m$.

10. The return on the 30 -year bond over 1 year is $30 y_{30, t}-29 y_{29, t+1}$. This equals 0.04 if $y_{30, t}=0.07$ and $y_{29, t+1}=0.071$.

11. The calculation is $30 \times 0.07=0.04+(29 \times 0.071)$.

12. This terminology is due to Lutz (1940). Hicks (1939) argued that long bonds should have higher average returns than short bonds because borrowers prefer long-term loans while lenders prefer short-term ones. Modigliani and Sutch (1967) generalized Hicks" "liquidity preference" theory to allow for any pattern of "preferred habitats" among borrowers and lenders, and thus any pattern of average bond returns with maturity. These authors challenged the pure expectations hypothesis, but not necessarily the expectations hypothesis.

13. This follows standard modern practice, although Froot (1989) argues that the expectations hypothesis fits the data better if expectations are taken from surveys. Melino (1988) emphasizes that the use of rational expectations has greatly clarified the previously confused literature on the expectations hypothesis of the term structure.

14. The regression estimated in the first row of Table 2 is $y_{m-1, t+1}-y_{m t}=$ $\alpha+\beta\left(y_{m t}-y_{1 t}\right) /(m-1)$. This contains the same information as a regression of the excess one-month return on a long bond on to the yield spread. The excess return regression would have a coefficient equal to one minus the coefficient reported in Table 2. Thus the estimates significantly less than one in the first row of Table 2 correspond to a significant positive relationship between yield spreads and excess returns on long bonds. Campbell and Ammer (1993), Fama and French (1989), and Keim and Stambaugh (1986) show 
that yield spreads help to forecast excess returns on bonds as well as on other longterm assets. Campbell and Shiller (1991) and Shiller, Campbell, and Schoenholtz (1983) show that yield spreads tend to forecast declines in long bond yields.

15. The regression estimated in the second row of Table 2 is $\sum_{i=1}^{m-1} y_{1, t+i} /(m-$ 1) $-y_{1 t}=\alpha+\beta((m-1) / m)\left(y_{m t}-y_{1 t}\right)$. The standard error for the coefficient $\beta$ is corrected for serial correlation in the error term. This regression contains the same information as a regression of $(1 / m)$ times the excess $m$-period return on an $m$-period bond onto the yield spread. The excess return regression would have a slope coefficient equal to one minus the coefficient reported in Table 2. Thus Table 2 implies that yield spreads forecast excess returns out to horizons of several years, but the forecasting power diminishes towards 10 years. Fama (1984) and Shiller, Campbell, and Schoenholtz (1983) report results of this type at the short end of the term structure, while Fama and Bliss (1987) extend it to the long end. Campbell and Shiller (1991) provide a comprehensive review.

16. This statement assumes that expected excess long-bond returns are not strongly negatively correlated with expected changes in short rates. Strong negative correlation between the two components of the spread could make the regression coefficient larger than one or in an extreme case could make it negative.

17. If irrational expectations are responsible for the results in Table 2, then one would expect the phenomenon to disappear in the long run - although the long run may come slowly if investors are slow learners. An argument that combines features of both the first and second explanations is that some investors ("noise traders") may have irrational expectations which influence market prices because rational investors are risk averse.

18. Both Figures 3 and 4 are based on data provided by the Federal Reserve Board. The Board estimates implied zero-coupon yields from coupon bond prices using methods described by Fisher, Nychka, and Zervos (1994). Forward rates are not shown past a maturity of 15 years because the estimates become very imprecise at long maturities.

19. Campbell and Ammer (1993) and Mishkin (1990a,b) emphasize that long-term bond yields vary primarily in response to changing expected inflation. 
20. At first glance, it might appear that the mean yield spread can be estimated much more precisely than the mean excess bond return, because the yield spread has a much smaller standard deviation than the excess return. But the apparent difference in precision disappears once one accounts for the fact that serial correlation in the yield spread increases uncertainty about its mean. Neither mean is estimated precisely enough in 1952-91 to identify any savings from altering debt maturities beyond one year. Of course, sample means in shorter periods are even less reliable. Some proponents of short-term borrowing look at the period since 1980, when average yield spreads and excess long-bond returns have been particularly large: for 10-year zero-coupon bonds, the yield spread has averaged almost 2 percent, while the excess return has averaged almost 4.5 percent. In the $1980 \mathrm{~s}$, the Treasury would have realized enormous savings by borrowing short, but this is not at all a reliable guide to the future.

21. Even the Congressional Budget Office (1993), in a detailed and otherwise intelligent report on debt management, endorses this view. A variant of the argument stresses the possibility of a financial crisis in which short-term debt could not be refinanced at any price. If this is a serious concern, the government can handle it as private borrowers do, by issuing floating-rate debt.

22. Sill (1994) is an accessible introduction to the irrelevance theorem with a numerical example. Sill also discusses optimal debt management more generally. 
FIGURE 1: Zero-Coupon Yield Curves

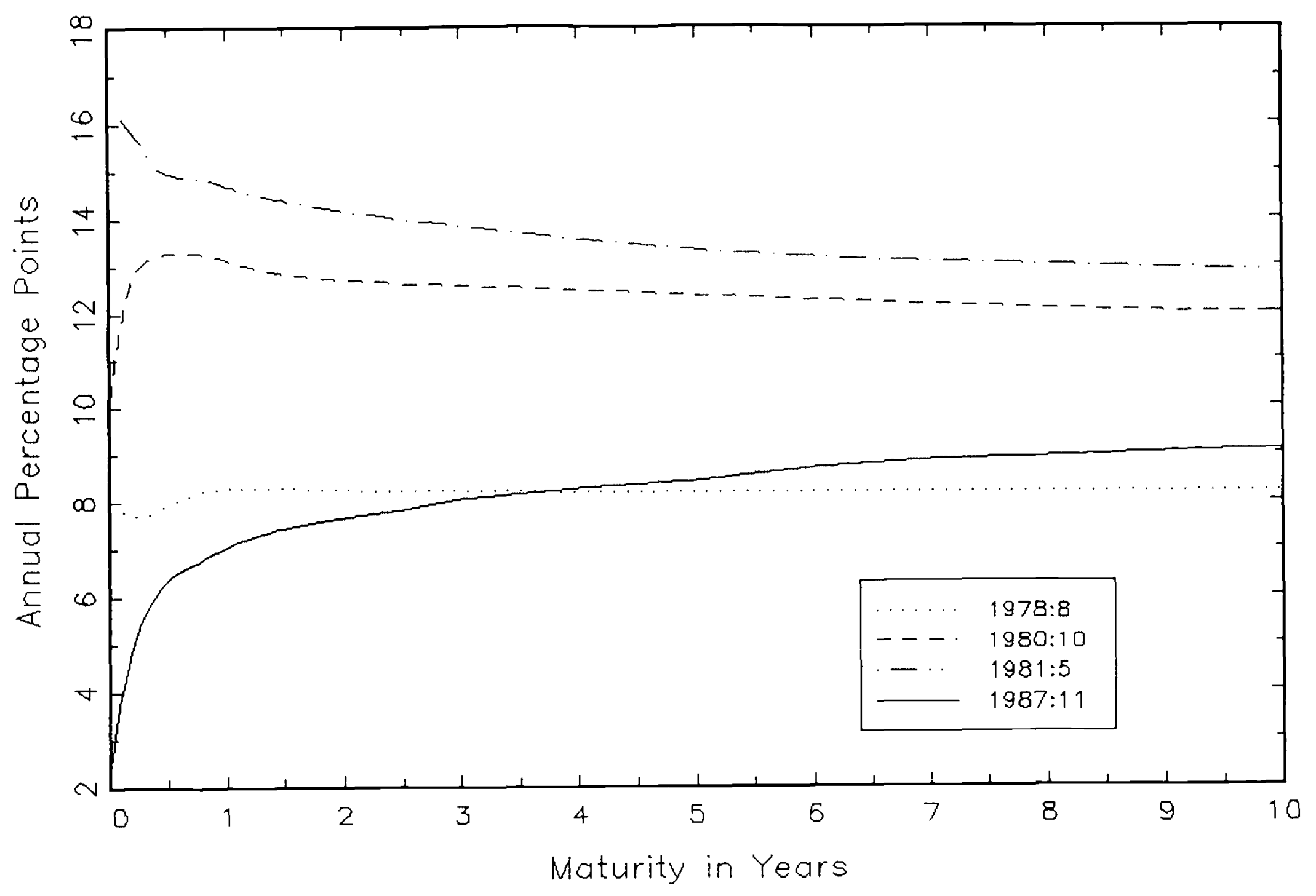


FIGURE 2: Zero-Coupan Yield and Farward Rate Curves 1/1987

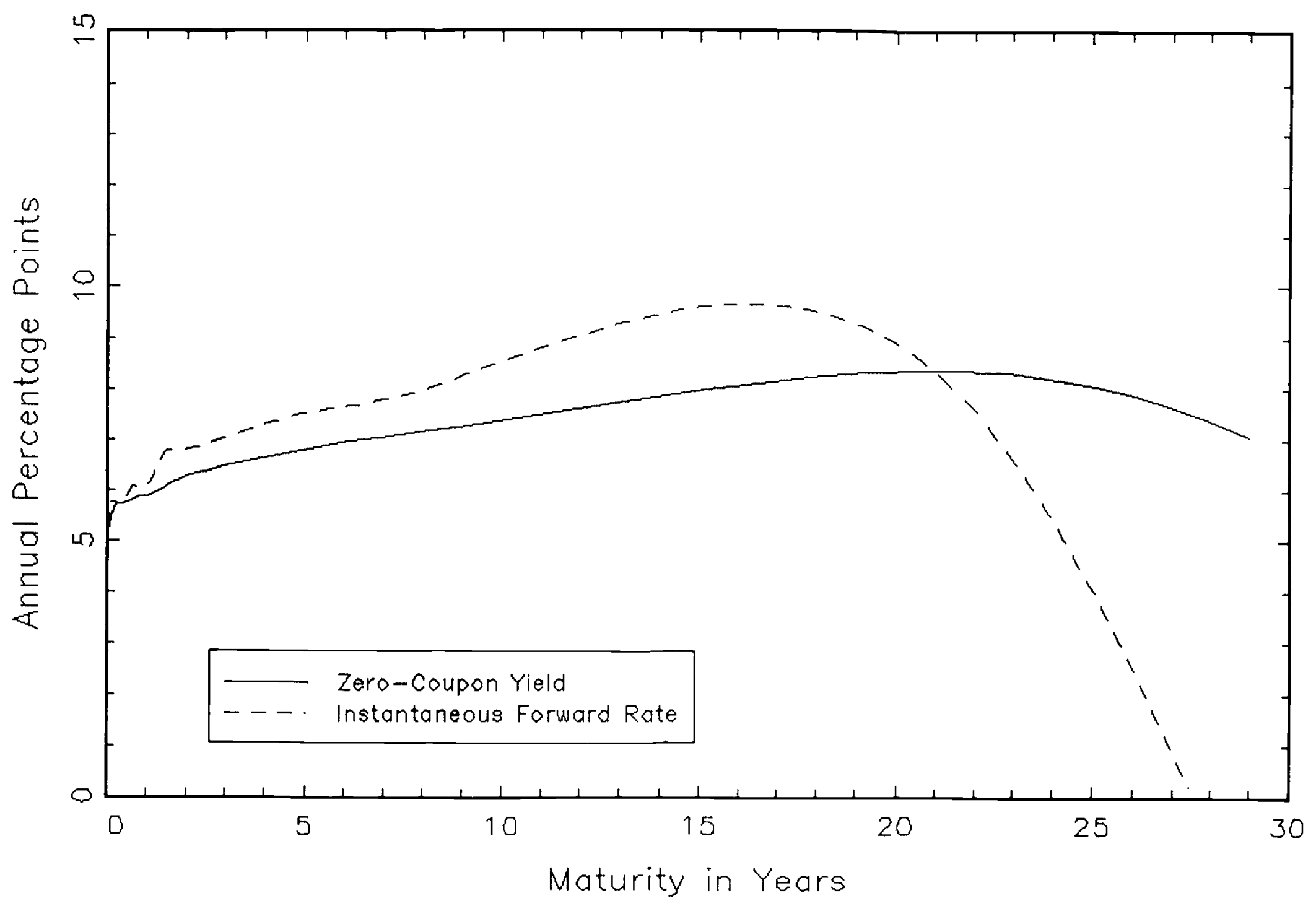


FIGURE 3: Zero-Coupon Yield Curves in Spring 1994

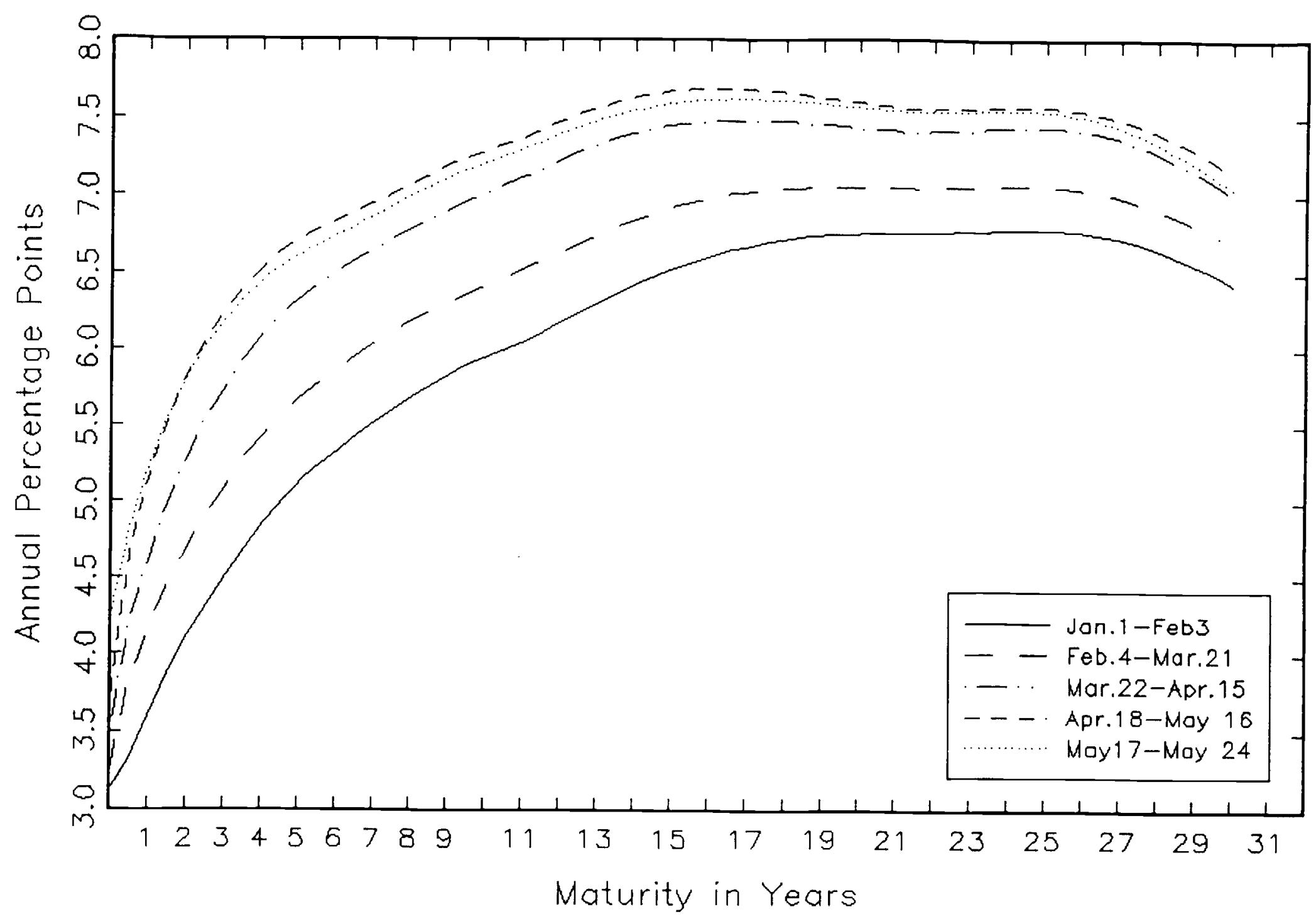


FIGURE 4: Forward Rate Curves in Spring 1994

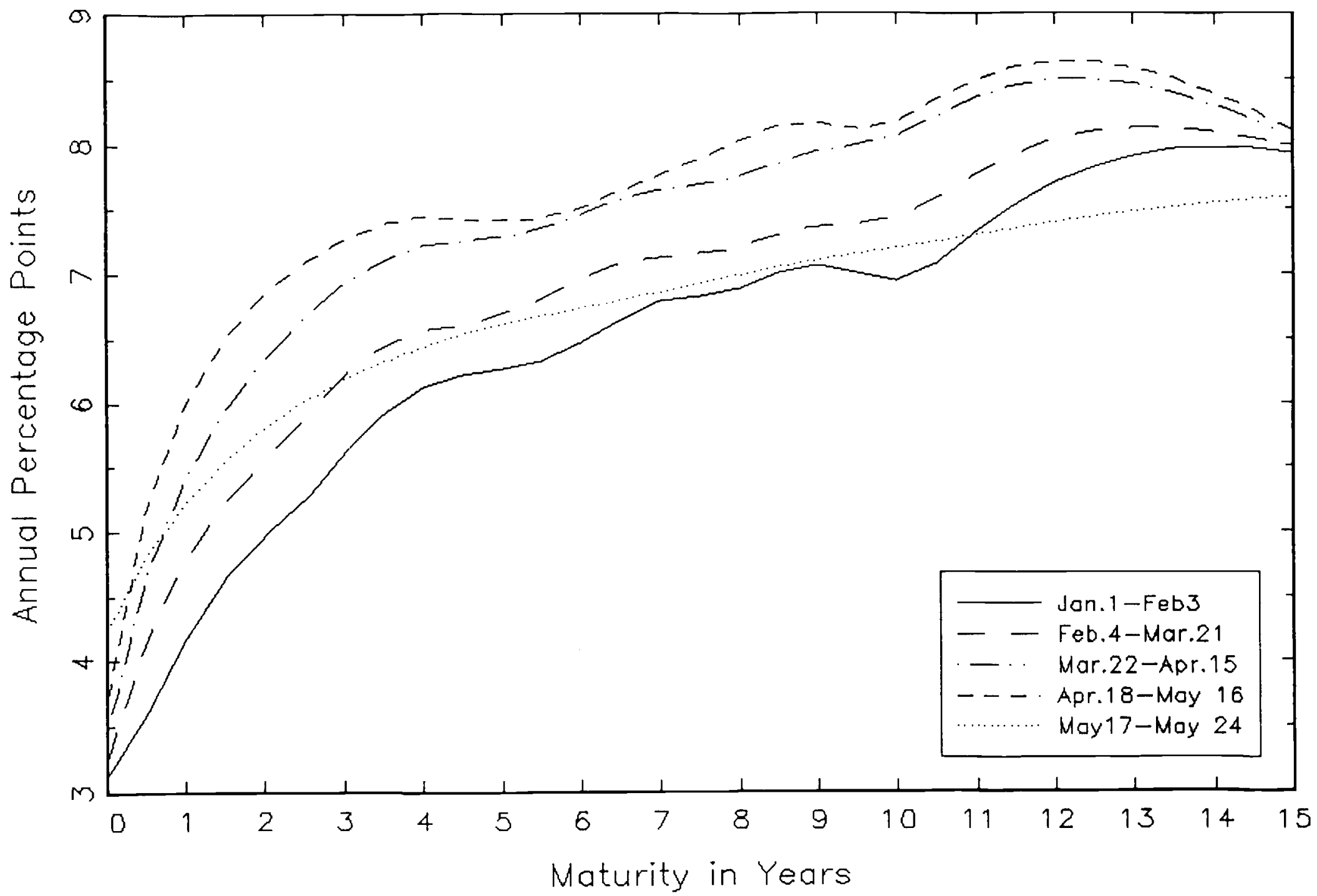

